\title{
Phytochemical Screening of Secondary Metabolites of Extracts of the Plant Ajuga Integrifolia Leaves
}

\author{
BIRHANU AYALEW TEBEJE* \\ Department of Chemistry College of Natural and Computational Science, \\ Post Box 196, University of Gondar, Ethiopia
}

\begin{abstract}
Ajuga integrifolia belongs to the family of Lamiaceae. The leaves were collected and extract prepared from petroleum ether, chloroform, ethyl acetate and methanol. Different types and effective compounds were qualitatively conformed using standard methods. These metabolites were flavonoids, phenol, alkaloids, flavonoids, glycosides, saponins, tannins, phenol, lignin etc. These metabolites show their high effectivity by which they belong to medicinal plant category.
\end{abstract}

Keywords: Ajuga integrifolia, secondary metabolites, Flavonoids, Alkaloids, Tannins, phenols.

DOI: $10.7176 / \mathrm{CMR} / 11-5-02$

Publication date:May $31^{\text {st }} 2019$

\section{INTRODUCTION}

Medicine and natural products have been closely interconnected through the use of traditional medicine. Still now, natural products are still providing their grate share of new clinical candidates (Newman DJ, Cragg GM, Snader KM. 2015).

Ethiopian peoples have their own set of written and or oral pharmacopoeias with the medicinal uses of some species being restricted to each ethnic group. Peoples in different zones/location with different religious, linguistic and cultural backgrounds have their own specific knowledge about use of plants which in part has gradually entered wide circulation in the country (Fekadu Fullas, 2001). These herbal medicines are much easier and cheaper to obtain than the synthetic medicines, and fewer side effects are reported. A locally cultivated Ajuga integrifolia is widely used in traditional medicine for treating diarrhea, stomach disorders, evil eye, retained placenta, ascariasis, malaria, swollen legs, hypertension, jaundice and wounds. It can also be used for veterinary purposes (Vohra and Kaur, 2011). A decoction of the leaves of the herb is used in the traditional medicine for a number of diseases including diabetes, hypertension, fever, malaria and stomach pain (Mirutse Giday et al., 2009).

Furthermore, qualitative phytochemical determination of Ajuga integrifolia leaves extract can gives more information about its biological activities. So this research plays a great role in determining the screening and content of phytochemicals of this plant using different solvents.

\section{MATERIAL AND METHODS}

\subsection{Plant description}

Ajuga integrifolia Buch.-Ham. (Syn: Ajuga remota; Ajuga bracteosa) is known by common names: 'Armagussa', 'Etse Libawit', 'Medhanit' (in Amharic). It is one of the species in the genus Ajuga and family Lamiaceae. The plants in the genus Ajuga are evergreen, clump-forming rhizomatous annual or perennial herbaceous flowering species in the mint family, Lamiaceae. There are at least 301 species of the genus Ajuga with many variations. Ajuga is one of the 266 genera of the family Lamiaceae (Vohra and Kaur, 2011).

Ajuga integrifolia, mostly known under the name Ajuga bracteosa, is a herb often lying on the ground and rooting at the nodes, covered with soft hairs, stems growing up to $40 \mathrm{~cm}$ high. Its leaves are coarsely toothed. Its flowers are small, pale blue, white or pale violet found in small clusters in the leaf axils. It flowers from late August to October while honeybees are frequently visiting the flowers for pollen and nectar (Fichtl and Admasu Adi, 1994; Ermias Dagne, 2009).

\subsection{Collection of Plant Material}

Ajuga integrifolia is found all over the world. I had collected the flowers from North Gondar district, Amhara region. North Gondar district located in the Semien Gondar Zone of the Amhara Region, Gondar is north of Tana Lake on the Lesser Angereb River and southwest of the Simien Mountains. It has a latitude and longitude of $12^{\circ} 36^{\prime} \mathrm{N} 37^{\circ} 28^{\prime} \mathrm{E}$ with an elevation of 2133 meters above sea level. 
Fig.1. location of North Gondar district in Amhara regional state, Ethiopia.

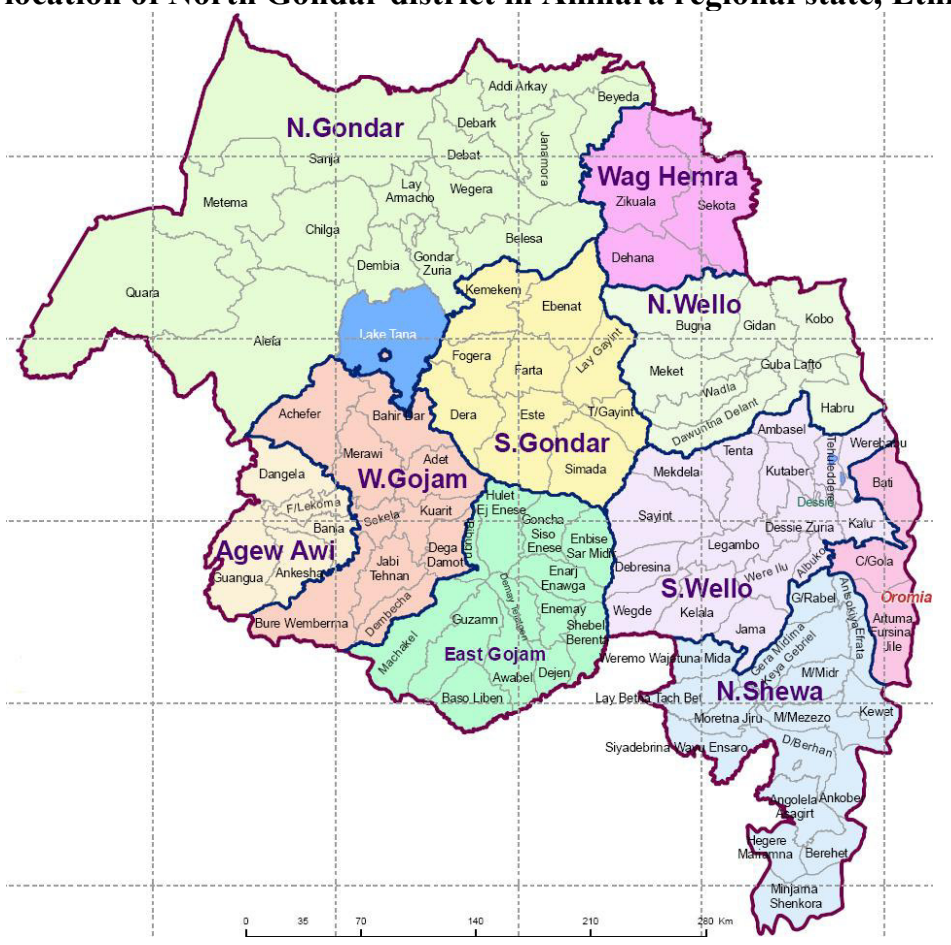

Fig.2. the plant Ajuga integrifolia

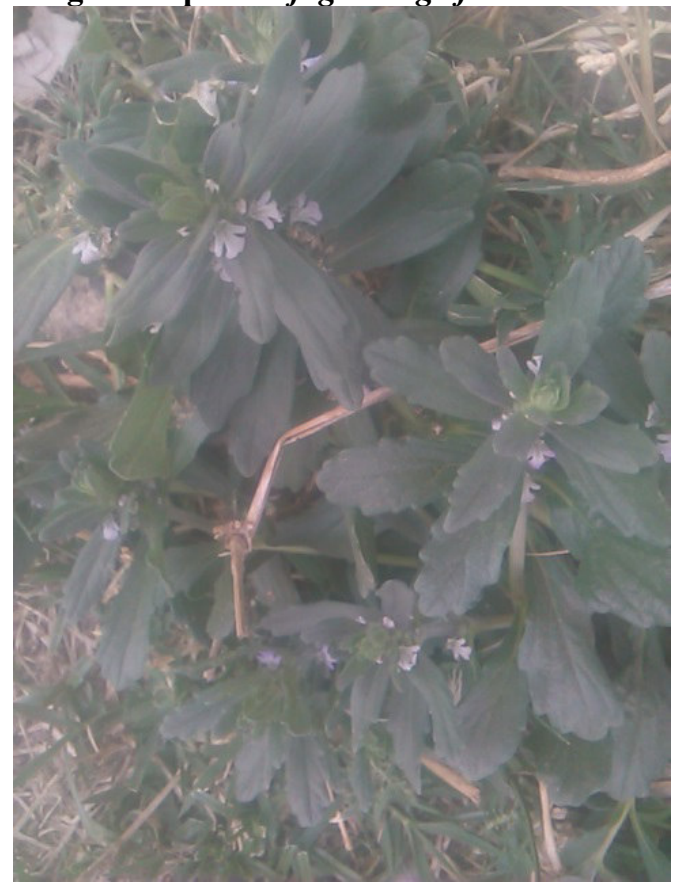

\subsection{Preparation of plant extract}

The leaves of Ajuga integrifolia used for the study were detach from the parent plant and washed with tape water to remove dust particles and other waste material from the surface of leaves. The leaves were placed in shaded and open place at room temperature for above 15 days to dry it with fresh air without exposing to sun light and heat. The air-dried leaves of Ajuga integrifolia were chopped in to small pieces and milled in to a uniform powder by electrical grinder. Each extraction were carried out exhaustively by maceration for 72 hours, using petroleum ether, ethyl acetate and chloroform. After this process, the extracts were filtered and used for preliminary phytochemical screening test. 
Fig. 3. Extraction procedure from the leaves of Ajuga integrifolia
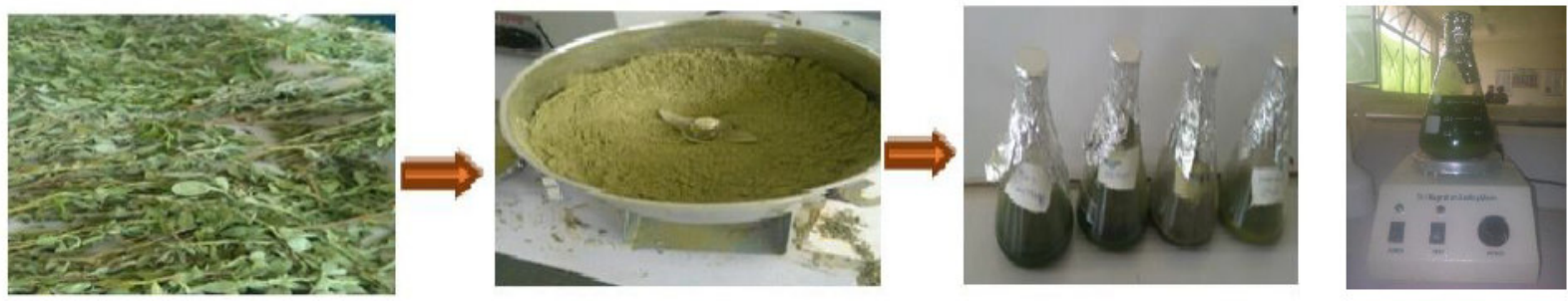

\subsection{Preliminary phytochemical tests for plant extracts}

The filtrate obtained by different solvent system was subjected to preliminary phytochemical screening.

Test for phenols

A small amount of the extract was taken with $1 \mathrm{~mL}$ of water in a test tube and 1 to 2 drops of Iron III chloride $(\mathrm{FeCl} 3)$ was added. A blue, green, red or purple color is a positive test.

Test for glycosides (Bontrager's test)

To $2 \mathrm{ml}$ of filtered hydrolysate, $3 \mathrm{ml}$ of chloroform is added and shaken, chloroform layer is separated and $10 \%$ ammonia solution is added to it. Pink color indicates presence of glycosides.

Test for flavonoids

One to five drops of concentrated hydrochloric acid $(\mathrm{HCl})$ were added to little amount of methanol extract of the plant material. Immediate development of a red color indicates the presence of flavonoids.

Test for alkaloids (Wagner's test)

A few drops of Wagner's reagent are added to few $\mathrm{ml}$ of plant extract along the side of test tube. The formation of reddish brown precipitate indicates alkaloid's presence.

Test for saponins

One $\mathrm{ml}$ of the extract was diluted with distilled water to $20 \mathrm{ml}$ and shaken in a graduated cylinder for 15 minutes. The formation of one centimeter layer of foam indicates the presence of saponins.

\section{Test for tannins}

Five $\mathrm{ml}$ of the extract was placed in a test tube and then $2 \mathrm{~mL}$ of $5 \%$ of $\mathrm{FeCl} 3$ solution was added. A greenishblack precipitate indicates the presence of tannins.

Test for terpenoids (Salkowski test)

In a test tube containing $2 \mathrm{~mL}$ of chloroform, $0.5 \mathrm{~mL}$ of extract was added. This is then followed by the addition of $3 \mathrm{~mL}$ conc. H2SO4 which forms a layer. Reddish brown coloration of the interface indicates terpenoids.

Test for Amino acids (Ninhydrin test)

The extract $(100 \mathrm{mg})$ is dissolved in $10 \mathrm{ml}$ of distilled water and filtered through Whatmann number 1 filter paper and the filtrate is subjected to test for Amino acids. Two drops of ninhydrin solution (10 mg of ninhydrin in $200 \mathrm{ml}$ of acetone) are added to $2 \mathrm{ml}$ of aqueous filtrate. Appearance of purple color indicates the presence of amino acid.

Test for Carbohydrate (Benedict's test)

To $0.5 \mathrm{ml}$ of filtrate, $0.5 \mathrm{ml}$ of Benedict's reagent is added. The mixture is heated on a boiling water bath for 2 minutes. A characteristic colored precipitate indicates the presence of sugar.

\section{Test for steroids}

To the plant extracts $2 \mathrm{ml}$ of chloroform was added. $2 \mathrm{ml}$ of conc. $\mathrm{H}_{2} \mathrm{SO}_{4}$ was added by the sides of the test tube and observed for red color at the lower chloroform layer.

\section{RESULT AND DISCUSSION}

The results of the phytochemical screening of leaves extracts of Ajuga integrifolia were present in Table-1. Different types of secondary metabolites such as terpenoids, alkaloids, flavonoids, phenol, saponins, steroids and tannins were presented. Intensive indication of flavonoids, phenols, terpenods and carbohydrates were found in methanolic extracts of Ajuga integrifolia leaves as compared to other solvents. Saponins were mainly present in the samples extracted from methanolic solvent. Amno acid were also found mainly in the methanolic extract of Ajuga integrifolia.

Alkaloids have different types of activities as pain-killers, antimicrobial, stimulants, muscle relaxants, anaesthetics, anti-microbial, anti-diabetic, anti-cancerous, anti-HIV, antioxidants etc. (Joshi et al, 2013). Flavonoids have inherent ability to modify the body's reaction to allergen, virus and carcinogens. They show ant-allergic, antimicrobial and anticancer activity by which it can be used for different diseases that is generally found in bark. Tannins have general antimicrobial and antioxidant activities (Joshi et al, 2013).

Saponins have anti-inflammatory, anti-heptatonic, hypoglycemic, anti-microbial and anti-viral properties (Visweswari et al. 2013). 

2013).

Phenols have anti-inflammatory, anti-oxidant, anti-cancer and anti-septic properties (Visweswari et al.

Terpenoids have anti-viral, anti-bacterial, anti-malarial, anti-inflammatory properties and it can inhibits cholesterol synthesis (Visweswari et al. 2013). From These contents show different types of activities against different pathogens. Therefore, it can be used in the treatment of diseases.

\section{CONCLUSIONS}

Based on the results in this research, it can be concluded that different solvent extract of the plant Ajuga integrifolia contain high levels of different phytoconstituents such as terpenoids, alkaloids, carbohydrates, phenols and flavonoids, so that they can be used in drug formulation.

\section{ACKNOWLEDGEMENT}

The author is thankful to Debre Tabor University for financial support and providing necessary facilities to carry out the work.

\section{Conflict of Interest statement}

The author has no conflict of interest.

\begin{tabular}{llll}
\multicolumn{3}{l}{ Table 1: Phytochemical Study of Ajuga integrifolia leaves } \\
No. & test & Pet ether & chloroform \\
1 & Phenol & + & + \\
2 & Flavonoids & + & + \\
3 & Alkaloids & + & ++ \\
4 & Saponins & - & - \\
5 & Tannins & - & + \\
6 & Terpenoids & + & ++ \\
7 & Carbohydrates & ++ & + \\
8 & Proteins & + & + \\
9 & Fat & - & - \\
10 & Amino acids & + & - \\
11 & Steroids & - & ++ \\
\multicolumn{7}{l}{+ Present, - Absent of the particular compound) } &
\end{tabular}

$\begin{array}{ll}\text { Ethyl acetate } & \text { Methanol } \\ + & ++ \\ - & ++ \\ + & + \\ - & + \\ - & + \\ ++ & ++ \\ ++ & ++ \\ - & \\ - & - \\ & + \\ + & -\end{array}$

\section{REFERENCES}

1. Newman D, Cragg G, Snader K. (2015). The influence of natural products upon drug discovery. Tropical Journal of Pharmaceutical Research.

2. Fekadu F. (2001). Ethiopian traditional medicine. Common medicinal plants in perspective. USA

3. Vohra, A. and Kaur, H. (2011). Chemical investigation of medicinal plant Ajuga bracteosa Organic Chemistry (Natural Product). J. Nat. Prod. Plant Resour. 1 (1): 37-45.

4. Mirutse Giday, Zemede Asfaw and ZerihunWoldu. (2009). Medicinal plants of the Meinit ethnic group of Ethiopia: An ethnobotanical study. J.Ethnopharmacol. 124 (3):513-521.

5. Fichtl R, Admasu A. (1994). Honeybee flora of Ethiopia. DED (German Development Service) and Ministry of Agriculture-Livestock and Fishery Resources. Weikersheim: Margraf Verlag.

6. Ermias Dagne. (2009). Natural Database for Africa (NDA). Addis Ababa, Ethiopia. Version 1.0.

7. NR Earnsworth, JP Berderka, M Moses. (1974). Journal of Pharmaceutical Sciences, 63, 457-459.

8. Joshi N, Bhatt S, Dhyani S, Nain J. (2012). Phytochemical screening of secondary metabolites of Argemone Mexicana. Linn flowers. International Journal of Current Pharmaceutical Research. 5(2): 144-147

9. Visweswari G, Christopher R, Rajendra W. (2013). Phytochemical screening of active secondary metabolites present in Withania somnifera root: Role in traditional medicine. Int J Pharm Sci 4(7): 27702776. 